\title{
تزكية النفس من خلال نصوص القرآن والسنة
}

إعداد: د. حنان محمد فضل المولى محمد

مقدمة

الحمد الله نحمده ونستعينه نسـتغفره ونسـتهديه، ونعـوذ بـالله مسن

شرور أنفسنا ومـن سيئات أعمالنا، وومن يهدي الله فهو المهتدي ومن يضلل فلا هادي له، و أشهد أن لا إله إلا الله وحده لا شريك له و أن محمدد عبـده ورسو لله.

تعتبر تزكية النفس شعبة من شعب الـدين الههمسـة وذلــك لحاجــة

الفرد و المجتهـع لهذه التزكية، وتهـدف الدراســة للوقـوف علـى مفهـوم تزكية النفس في اللغة والاصطلاح و القر آن الكريهم و أهدافه و ثمرته فـي

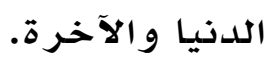

و تكمـن مشكلة الدراسـة في الإجابة على عـدد مـن الأســـلة: مــا هـو

التعريف لتزكية النفس؟ و ما هي أهدافها؟ و مـا هــي فوائـدها للفـرد فـي

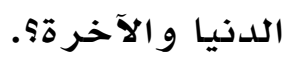

استخدمت الباحثة في هذه الدراسـة الهنهج الوصفي التحليلي بعسرض الهعلوومات التي تتصل بتزكية النفس، ثم تحليله وفق مـا يحقـق أهـداف

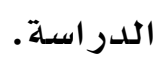

تشمل الدراسـة ملخص البحث باللغتين العربية و الانجليزية، مقدمسـة،

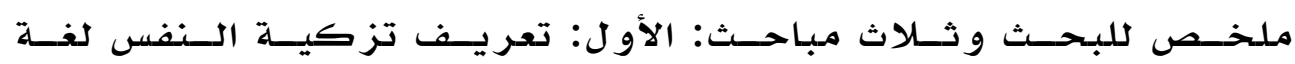
و اصطلاحاً و تعر يفها في القر آن، و الثاني: أهداف تزكية النفس، و الثالـث: الفوز في الدنيا والآخرة، الخاتمـة و تشمل أهم النتائج والتوصيات. 


\section{مستخلص}

رسالة الإسـلام رسالة علم وبنـاء وحضـارة ورسـالة خيـر ووسـية

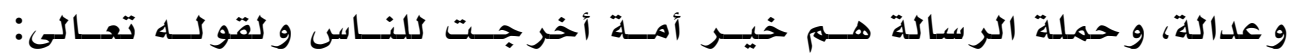

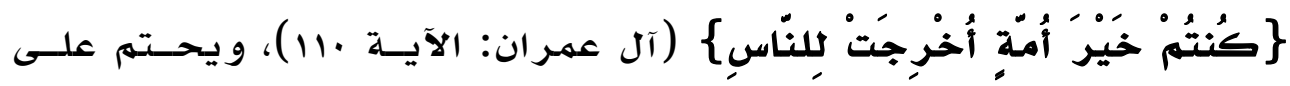
هذه الأمهة اليوم أن تعود بهنهج تز كية النفس حتى تحافظ علـى كيانهـا

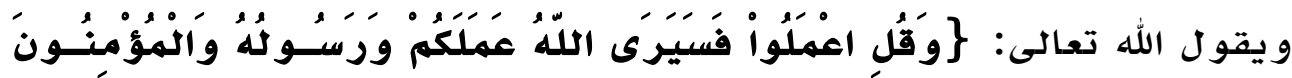

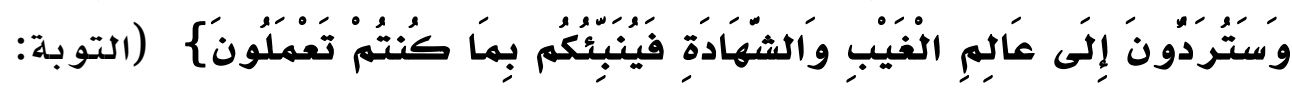
(1.0) (1) الآيلة

القر آن الكريهم ينوه بشعبة من شعب الدين، ومههة مـن مهمات النبوة، يعبر عنها بلفظ تزكية النفس، فإنه الدرع الواقي والحصـن الهتــين مسـن الوقوع في الأزمات و النكسات.

و أهداف تزكية النفس: تهذيب الأخسلاق، و أنهـا تخلـق لنــا مـجتهـع معافى صالح ليس له شبيه في العالم وتحليها بالفضائل (الإخلاص، الخوف مـن الله، الشكر و التواضـع)، و يتخخل عن الرذائلـل (الشــح، والعجــب، التكبـر، و الرياء) و إقامـة الشعائر الدينيـة بخشوع وتدبر، وتزكية النفس لا تكسون إلا بالتخلق بأخلاق القر آن، و إتبـاع السنـة النبـويسة، والصسـلاح و الفـلاح فـي الدينا و الآخرة.

و توصل الباحث إلى أهم النتــائج: أهميـة تزكيــة الـنفس بـالقر آن

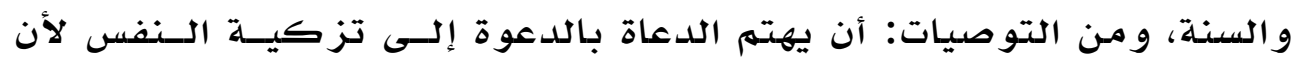
فيه إصدلاح الهـجتمعات، ووكذلك الأفر اد. 


\section{Abstract}

Islam message is mission of sciences, structure, civilization, justice and mediation. The massage's holders are the best nation whom sent out to the people, the almighty said that

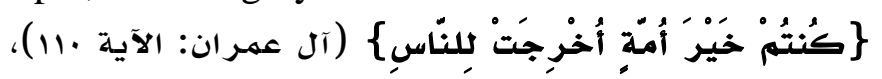

Today, this nation must return to the self-righteous approaching order to maintain its existence the almighty say in eltoabah surt

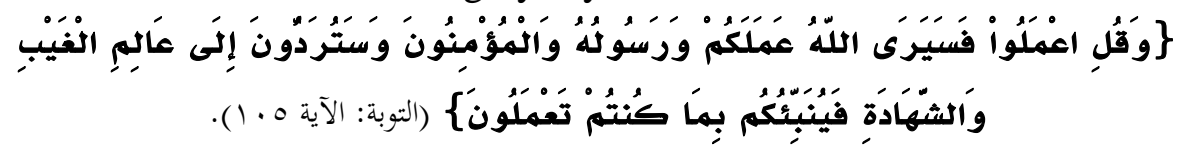

The holly Quran rekers to the ivisim of the religion divisions the missim at the mission of prophecy and while expressed by world self righteous the holly Quran is protective shield and solid of fortress of fortress of flowing into crises and setback.

The goals the self purifiution are retirement of ethics and creahig a healthy and good society has no resemblance in the world and is virtues such as devotion far of allar thenks giving and humility incepting away from vices sucl as surety pride arrogance and lypocity moreover doing the religious rituals devoutnessly and forethoaghyly the religious pride arrogance and lypocrisy moreover doing the religious rituals devoutness and forethoaghyly the self purification will not be unless characterized by ethics of Quran and following the prospering this lie and hereafter.

The reseal come and of the results its most ingoted are the inporfal of self punifiching by Quran and sun rah recommendation is the preachers should encouraged to call self purification because if reformed societies as well as individuals. 


\section{المبحث الأول \\ تعريف تزكية النفس لغة واصطلاحاً وتعريفها في القرآن \\ أولاً: النفس لغة واهطلاحة: \\ / النفس لغة: أنة:}

"و يقال خرجت نفسه أي: روحه و الدم يقال مـا لا نفس له سـائلة أي

لا دم وذات الشيء و عينـه يقال: جاء هو نفسـه أو بنفسـ، والعين يقال نفسـه

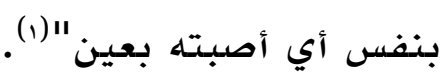 / النفس اصطاً:}

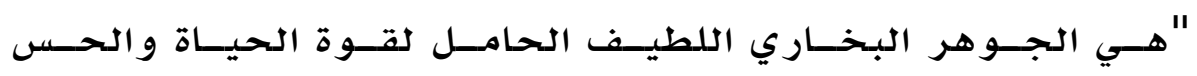

$$
\text { والحر كة الإر ادية وسهاهـا الحكيه: }
$$

أ- النفس الأمـارة: هي التي تميل إلى الطبيعة البـنية وتــأمر بـابــات

و الشهو ات الحسية و تجذب القلب إلى الجهة السفلية فهـي مـأوى الشــرور و منبـع الأخلاق الذمـيمـة.

ب- النفس القدسية: هي التي لها ملكــة استحضــار جهيـع مــا يهكـن للنوع أو قر يباً من ذلك على وجه يقينـي وهذا نهاية الحس. ج- النفس اللوامسة: هي التي تنورت بنور القلب قد مـا شبهت بــه عـن سيئة العفة، كلها صدرت عنها سيئة بحكم جبلتها الطمأنينة أخـذت تلـوم نفسها و تنوب عنها. د- النفس الهطمئنة: هي التي تهم تنورها بنور القلب حتى انخلعت عن

صفاتها الذميهمة و تخلقت بالأخلاق الحهميدة" (r). نلاحظ في هذه التعريفات كلنفس أنها كيان الإنسـان و أسـاس وجـوده و مـا يدل على تأثير ها في بيته و عملـه، و مـجتهعهـ. 
ثانياً: التز كية لغة واهطلاًا:

/ التز كية : لغة:

في معجم لسـان العرب نجد أنه أجمل كثير مسـن مسادة زكـا عنــــا

قال: "و أصل الزكاة في اللغـة الطهارة والنهماء والبركة و المدلح هي زكـا يزكو زكاء وزكو أو تزكية وزكاة، وتدل على ثلاث معـاني: الهعنـى الأو ل: النهاء والزيادة و البركة، و الهعنى الثاني: الطهارة و الهعنى الثالث:

\section{الصلاح و التقى "(r)"

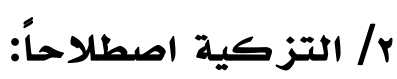

أ/ يقول الإمـام الغزالي: "أي السلوك معر فة تز كيـة الــنفس وقطـع

عقبات الصفات الههلكات و تحليتها بالصفات الهنجيات"(؛) . ب/ يعر فه الإمام ابن تيهـيـة: "و الزكاة في اللغة النهاء والزيـادة فـي

الصدلاح، يقال: زكا الشيء إذا ذها في الصـلاحح فالقلـب يحتـاج أن يتربـى فينهمو ويزيد حتى يكمل ويصلح كمــا يحتـاج البــدن أن يربـى بـالأغذيــة الهصلحة له، وكذلك القلب يزكو فينهو ويتمم صلاحه بحصو له ما ينفعه

$$
\text { ودفع ما يضره }
$$

ثانثاً: تعريف تزعية النفس في القر آن:

"ذكرت النفس في القر آن الكريهم بـأوجه كثيرة يقـول الله تعـالى:

\}ومَأ تَهوَى الْأنفُسُ نَفسبي

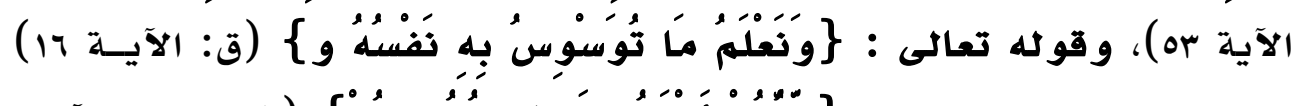

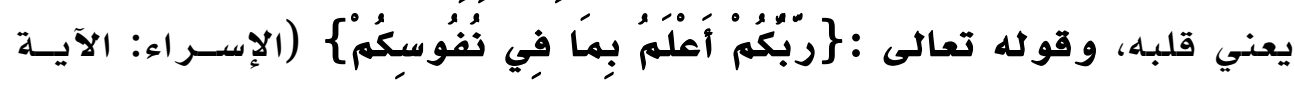
. (ro 


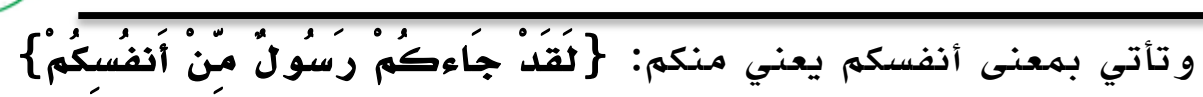

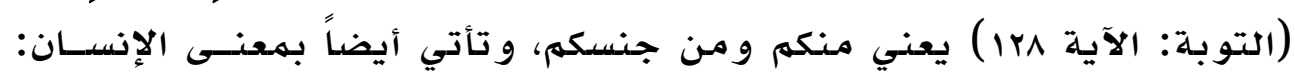

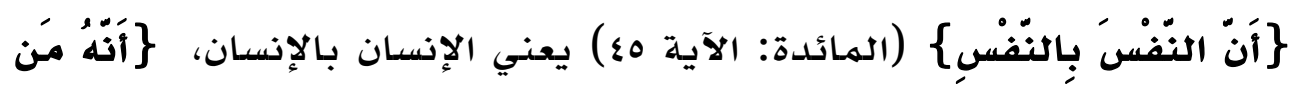

قَتَلَ نَفْساً بغِيَرِ نَفْسِِ

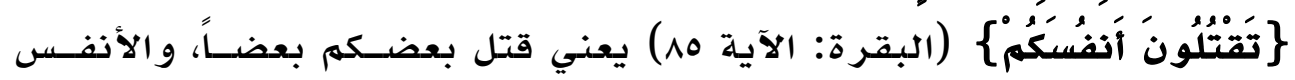

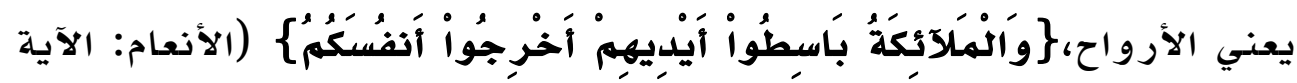

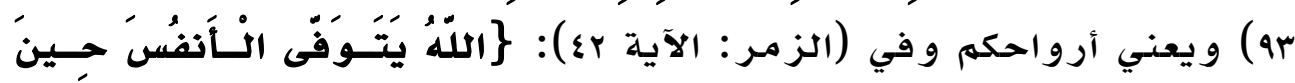

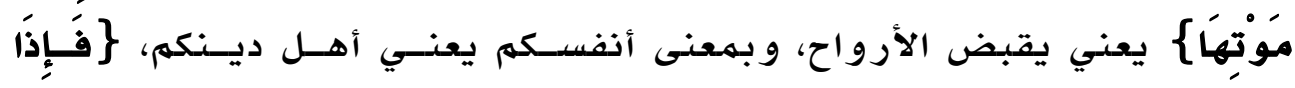

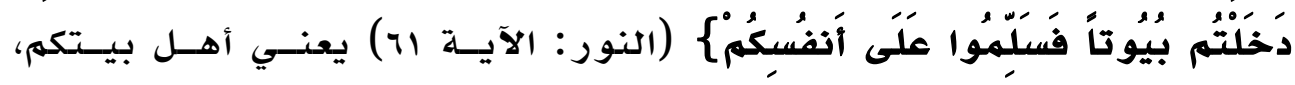

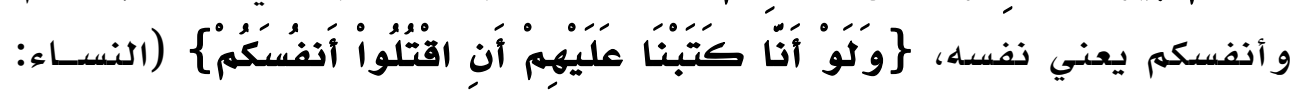

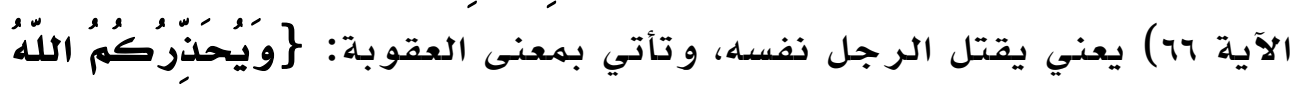

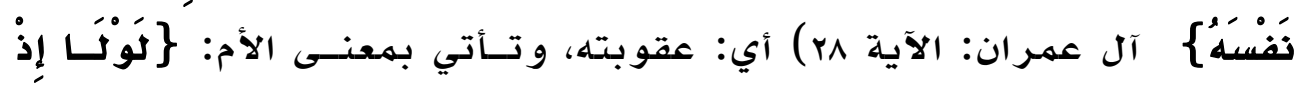

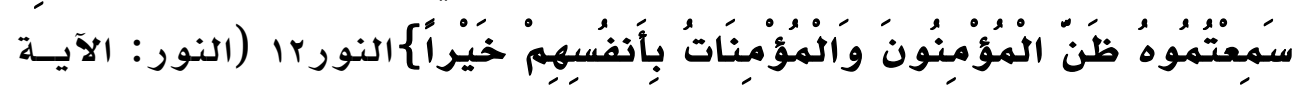

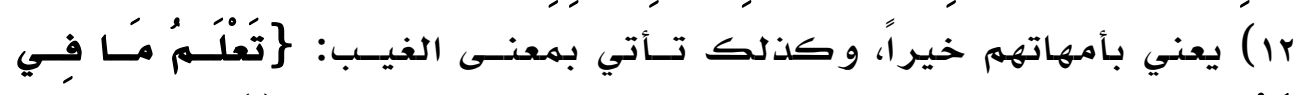

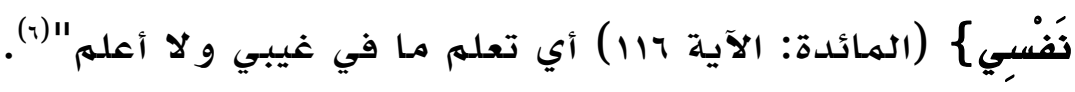
تزكية النفس في القر آن:

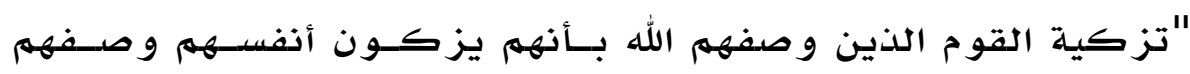

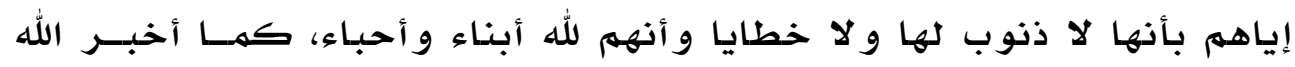

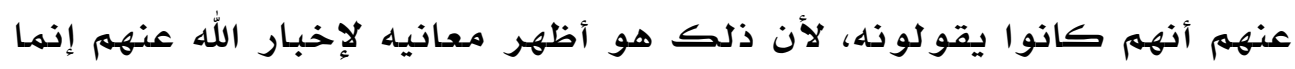

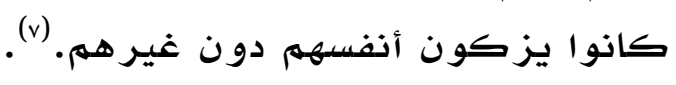

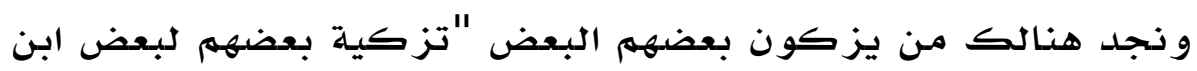

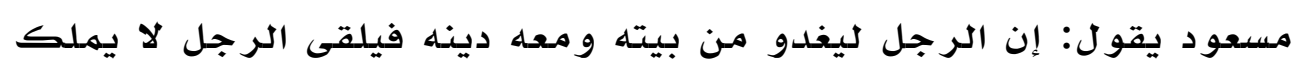

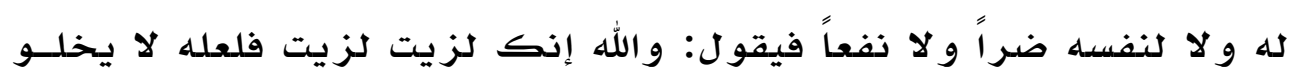

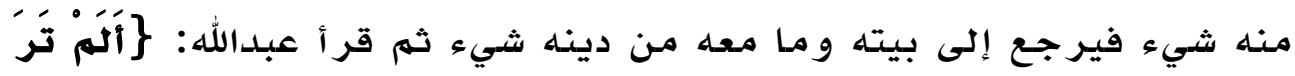

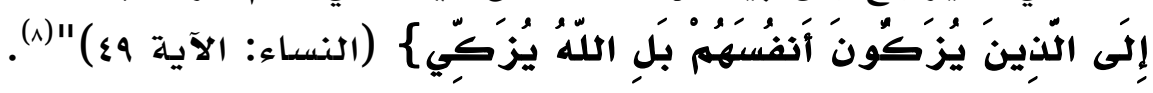


فالإنسان يجب عليه تزكية نفسه حتى لا تصل إلى المحارم ويقـول

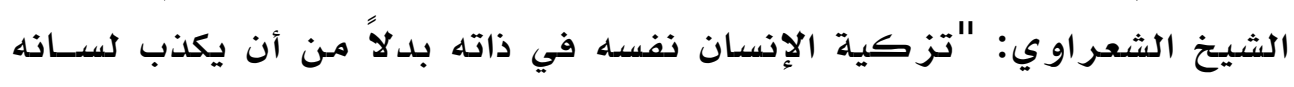

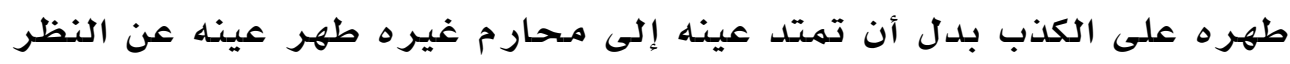

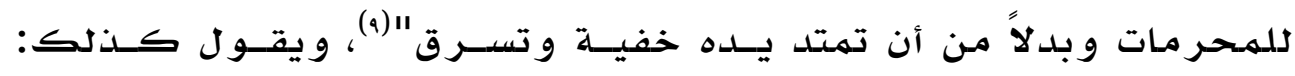

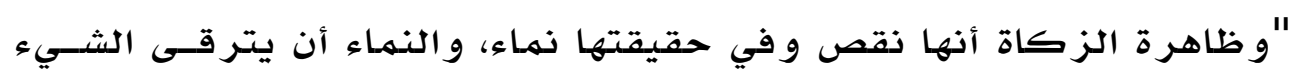

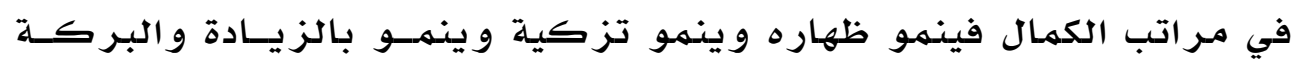

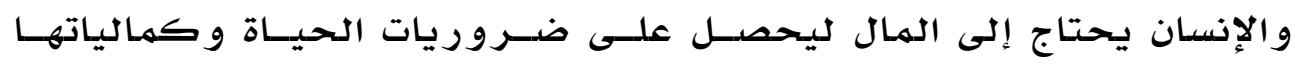

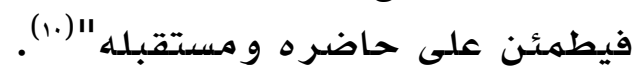

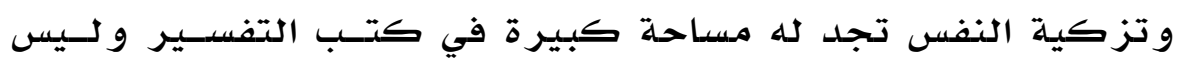
هناك مجال لذكر ها من كتب و هذه تعاريف له من بعض كتب التفسير . 


\section{المبحث الثثاني \\ أهداف تزكية النفس}

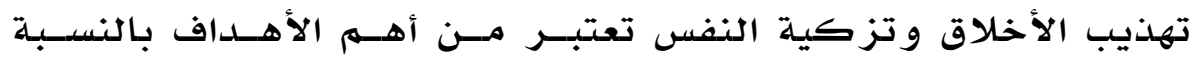
للبشر يـة جهعاء، وتعود على الفرد بـالفائدة العظيهـة، وتجعله إنسـاناً سـوياً و مستقر اً نفسياً، ومـرتاح الضهير، و يقوم بواجبـاتها التي تتعلق بأمور الدين و الدنيا لأنه يؤديها بـأمـانة و صدق. و تعتبـر تزكية النفس ركــن مـن أهـهم الأركان، ويقول الشيخ الندوي: "و إذا رجعنـا إلى الكتـاب و السـنـة و عصـر الصحابة و التابعين وتأملنا من القر آن والحديث و جدنا القر آن ينوه بشعبـة مـن شعب الدين، و مههمة مــن مهمهـات النبــوة يعبـر عنهــا بلفـظ التز كيـة و يذكر ها كـركن مسن الأركـان الأربعـة التـي بعـث الرسـول الأعظـم

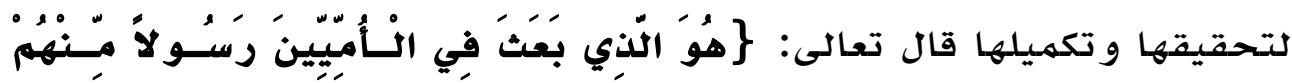

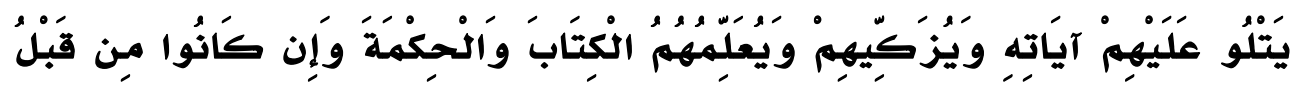

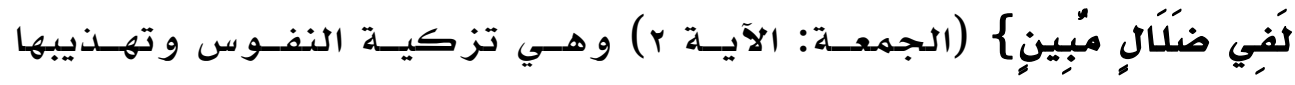
وتجليتها بالفضائل وتخليتها من الرذائل، التزكيــة التــي تـرى أمثلتهـا الر ائعة في حياة الصحابة رضوان الله عليهم و إخلاصهم و أخلاقهم "(11). و بهذه التز كية ظهر ونهى لنا مـتمهع صالح ليس له شبيـ في العالم مـا يتمتح بـه من عدل وإحسـان "الهـجتهـع الصـالح الفاضل الهثالي الذي ذيس له نظير في التاريخ وهذه الحكومـة العادلة الر اشدة التي لا مثثيل لهـا فـي العالم ووجدنا لسـان النبوة يلهج بـرجة هي فوق درجة الإسـلام والإيهـان، و يعبـر بلفظ الإحسـان ووعناها كيفيته من اليقـين والاستحضـار يجسب أن

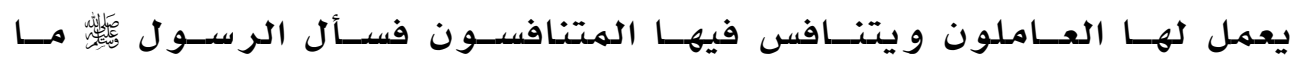

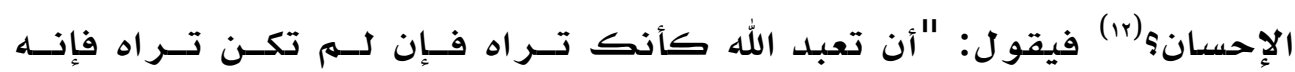

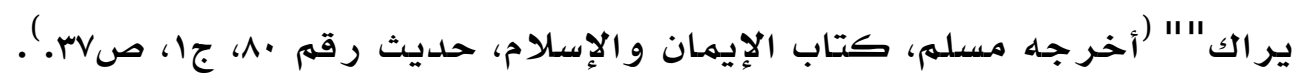


ومن أهم أهداف تزمية النفس الجـانب التعبدي الشعائري وذذلك في

عبـادات الإسـلام الكبـرى و الصـلاة، و الزكـاة و الصــيام و الحــج و آثارهــا فـي النفس و الحيـاة، و إقامـة هذه الشعائر بخشوع و تلدبر وخوف مـن الله تـذكر النـاس بـالدار الآخرة، و يـحهمل لهم العهل الصـالح لهـرضـاة الله وتصــر فـي أعينهم زخارف الدنيا و متاعها، و تأخذهم بالجد و السعي المتو اصل للنهو ض بالأمـة الإسلامية و إحياء الروح الجهادية في نفوس أبنائها ووهذا كله يخلق لهم أجواء روحانية عالية تأخذ بهـامـع القلوب وتثير النفوس. و أهداف تزكيـة الـنفس تكـون بتهـذيب الأخـلاق وتز كيـة الـنفس و تخليتها عن الرذائل وتحليتها بـالفضائل "الأخـلاق الرذذيلــة هـي الحجـبـ الصفيقة التي تمنع مـن الانتفاع بالتعليمات النبو يــة، والانطبـاع بصــة الله و هي التي تجعل الإنسـان فر يسـة النفس و لعبـة للشيطان وتعر ضــه للخطـر

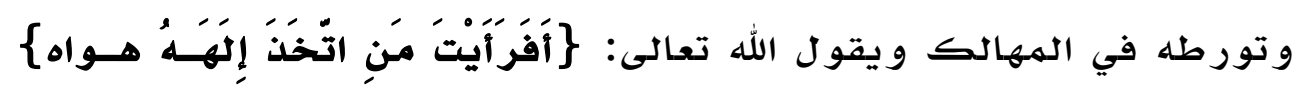
(الجـاثية: الآية سب) و يجب أن تخضع في ذلـك لهقيـاس الكتـاب والســـة و التعليهـات النبوية وتحكهها في أنفسنا و أخلاقنا و الإنسان مههما أوتـي مــن الذكاء وبعد النظر ودقة الملاحظة لا يرى و جهه إلا في مـر آة، والسـعيد من اطلع على مـواضـع الضعف عنده، والأمـر اض الخلقية التي هو مبتلى بهـا كالكبـر ، و الحسـل، و الطهـع، و الشر، و الشح، و الحر ص، و الحقــل، و الضــينـة و حب الـدنيا، وحـب الهــال الزائـل، واحتقــار الهسـلهم فيتشــاغل بـازالتهــا و التخلص منها، و يجاهد في سبيلها كمها يجاهد الإنسـان في عمدــه، وسـيــ من وجد المتدينين، والهـربين الحساذقين مـن نبهه علـى ذلـك وووصـف لـه طرق التخلص منها و يشر ذلك له، وسرى ذور قلبه إليه و أثر فيه إنصافه لنفسـه و لغيره و اعتبر بشدة مححاسبتـه لنفسـه، وتور عه وخشيته لله "ا(I). 
و القيهم الأخلاقية الفاضلة التي جاء بها الإسلام نتاج الإيهـان الصسادق

و العبادة الخالصدة لله تعالى، وبذلك فإن القيم الأخلاقية أصلية في الـدين.

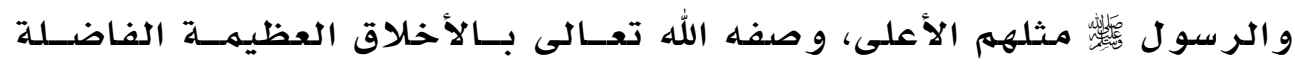

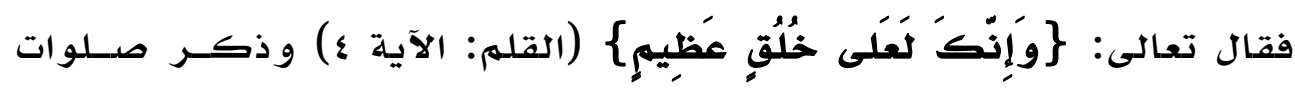
الله عليه و سلهم أن من مقاصد بعثته مكــارم الأخـلاق "إنهـا بعثـت لأتهــم

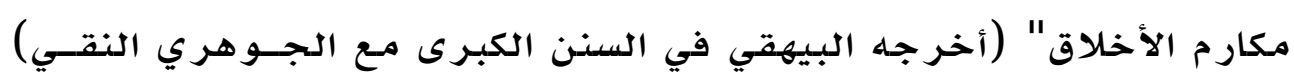

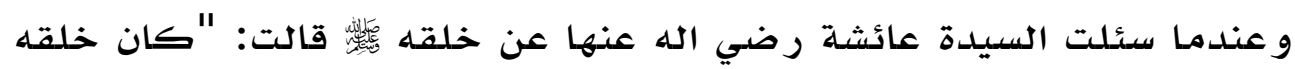
القر آن" (أخرجه البيهقي في السنن الكبرى، كتاب الصلاة، حديث رقسم r، ص99ء.) و كانت هذه الحكمة والتزكية من أعظم ثمرات الصحبة النبوية

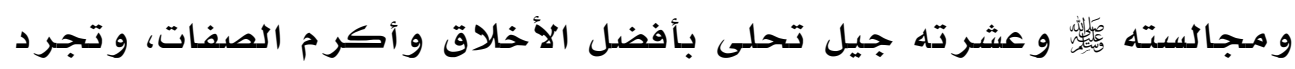
عن رذائل الأخلاق، وقد شهد القر آن باسـتقامـة قلـوبهمه ووصـلاح نفوسـهم،

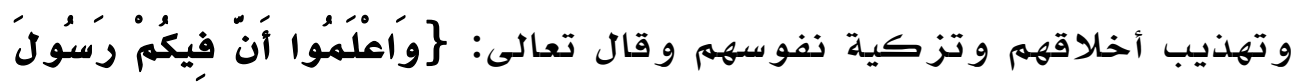

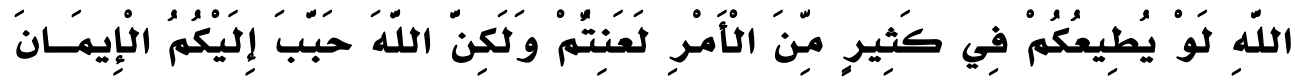

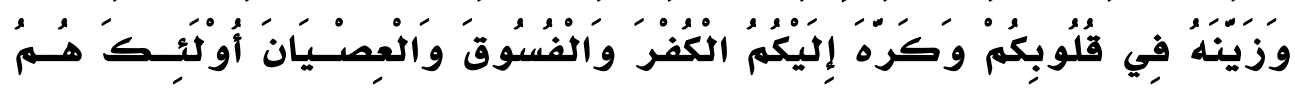

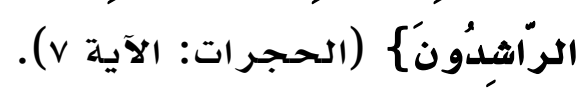

تزكية النفس و تهذيب الأخلاق بالمدرسة الربانية، وهنالك آيات من

القر آن وهي تعليمات أسـاسية لتهذيب الأخــلاق وتزَكسي النفـوس وتزيـل السموم من النفوس، ومكايد الشيطان، و أمراض القلوب، و لا يوجد له مثال في القوة، فإنها تنزيل مـن حكيهم حميلد، وتعليهم من النبي عليه السلام الذي

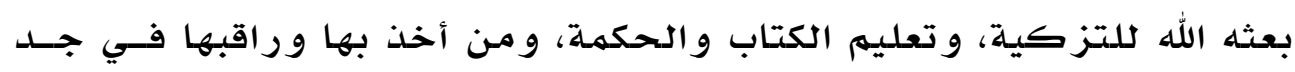
وصر امـة و في إخلاص و أمانة بلغ الغايسـة مسـن تهـذيب الأخسلاق وتزكيـة 
النفس و إذا أخذ بها فرد سعد وتزكى، وإذا أخذ بها مسجتهع كان مهتهعساً مـثالياً. و مـن أهم الآيـات و الأحساديث الواردة في تزكية النفس: أو لً: القر آن الكريه:

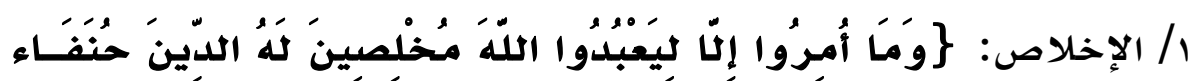

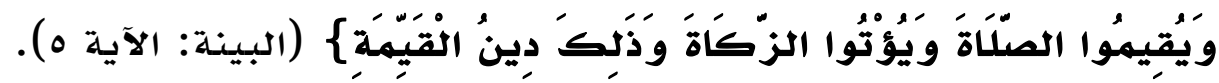

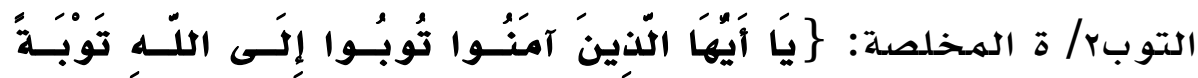

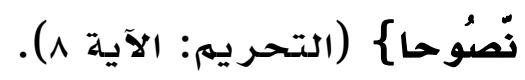

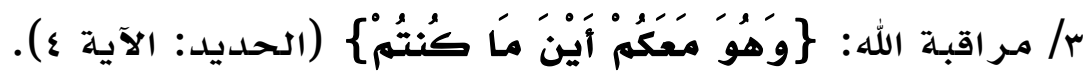

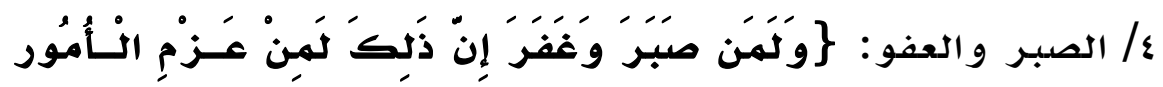
(الشورىى: الآيةتىع).

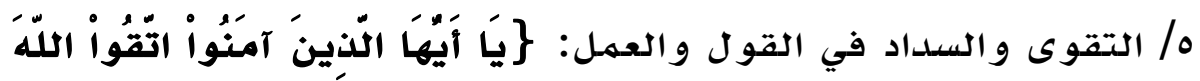

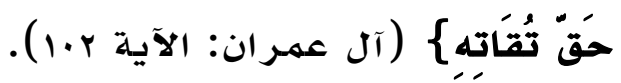

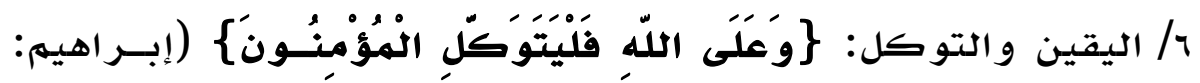

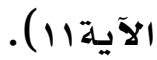

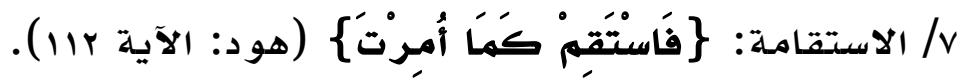

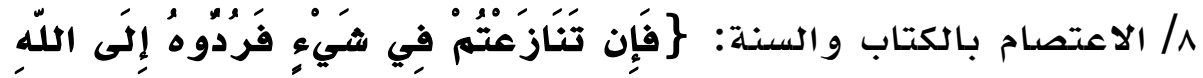

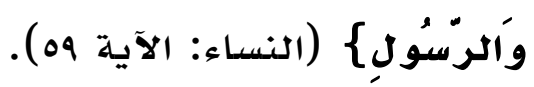

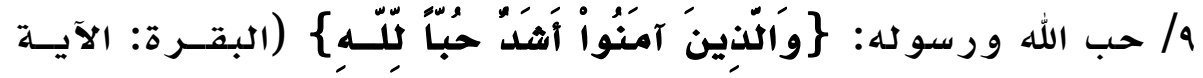
.$(170$

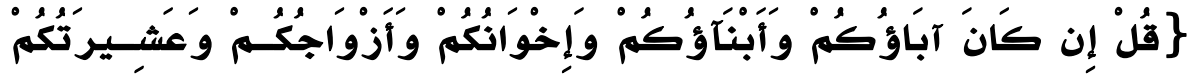

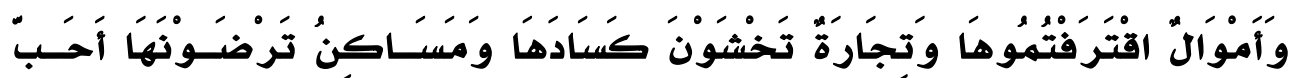




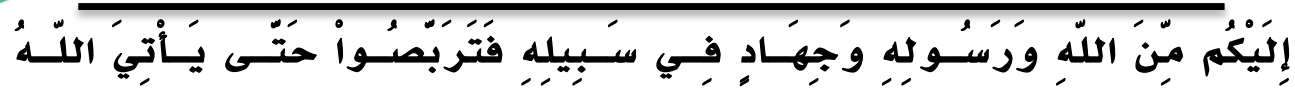

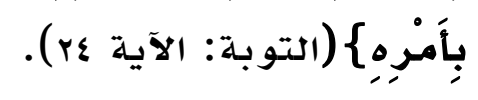

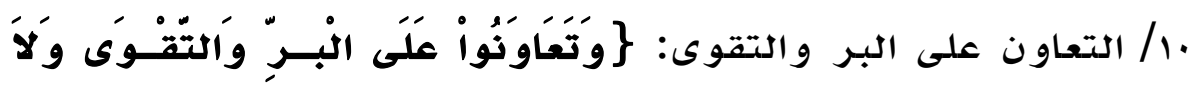

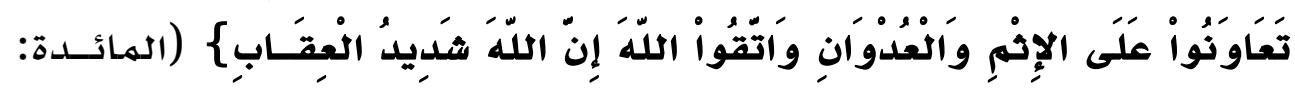

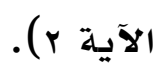

/11/ الأخوة الإسلاميلة: $\}$

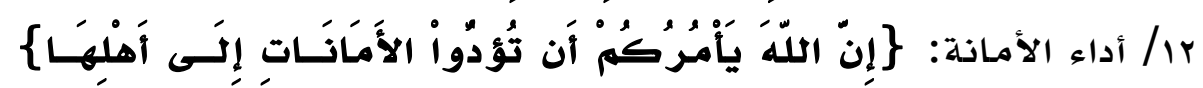

$$
\text { (النساء: الآيةهمه). }
$$

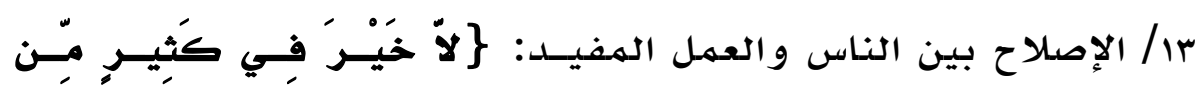

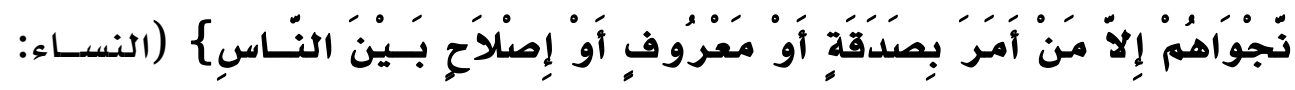

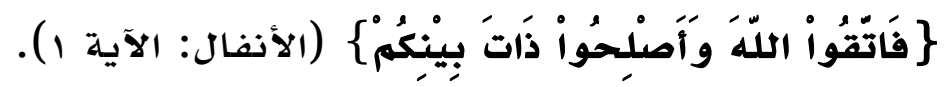

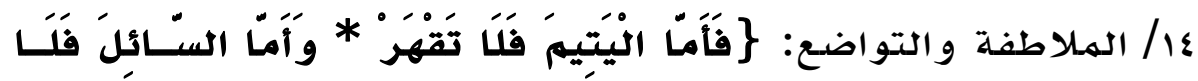

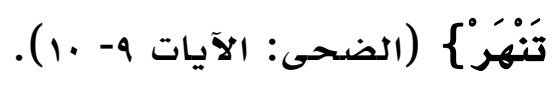

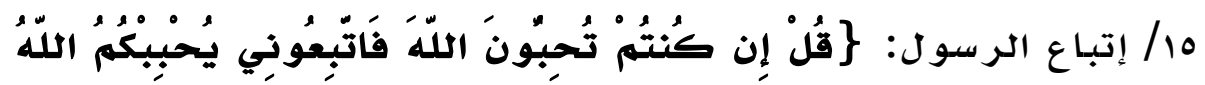

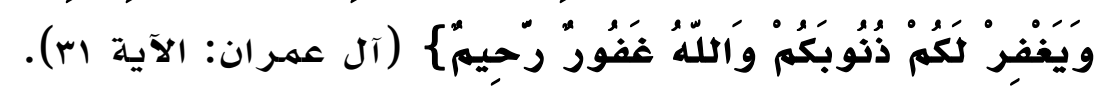

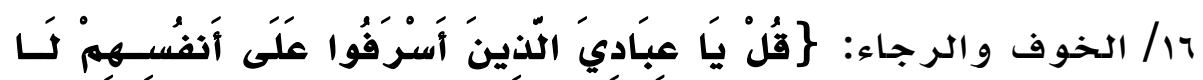

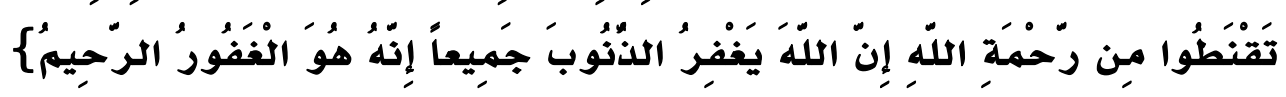

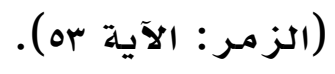

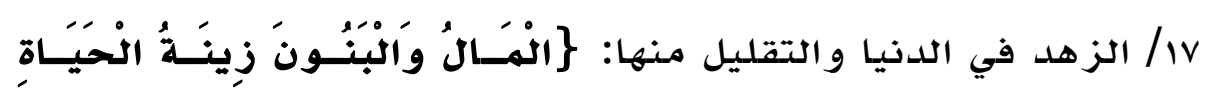

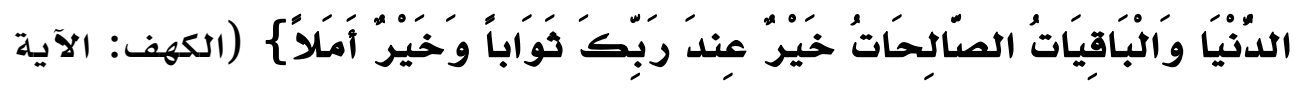




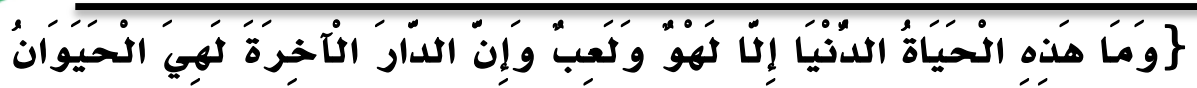

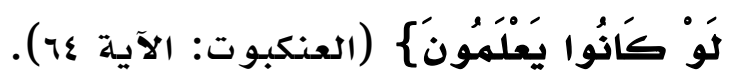

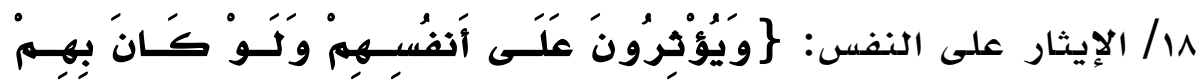

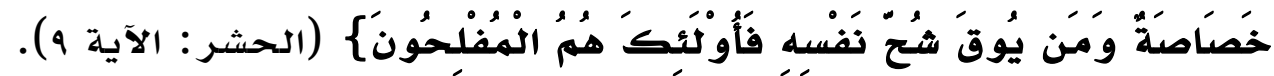

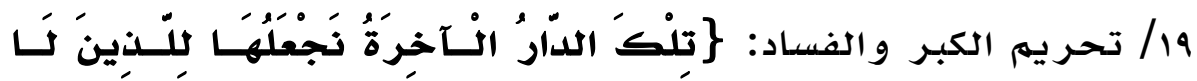

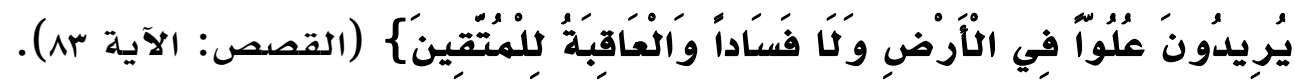

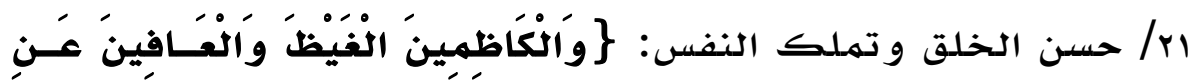

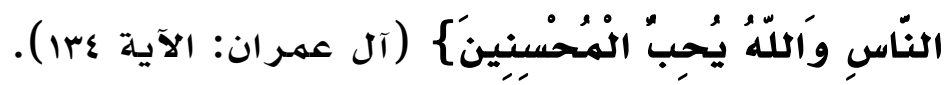

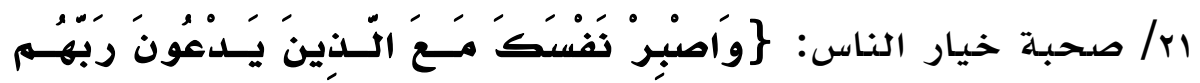

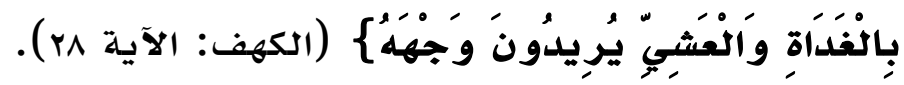

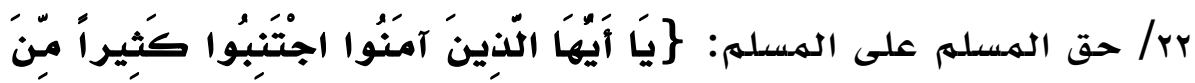

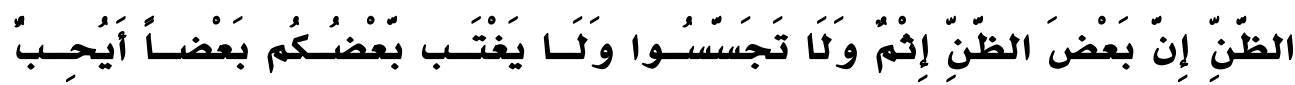

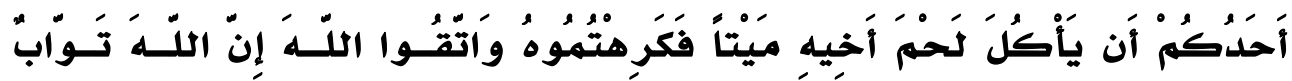

$$
\begin{aligned}
& \text { رَحيمُ\{ (الحجر ات: الآية rا). } \\
& \text { ثانياً: الأحاديث: }
\end{aligned}
$$

/ أهمية سلامة النية: "إنها الأعمال بالنيات و إنها لكل امرئ ما نوى

فهمن كانت هجر ته إلى الله ورسو له فهجر ته إلى الله ورسو له و من كانـت

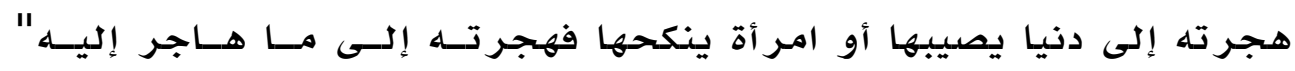

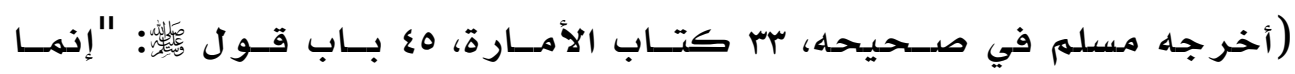

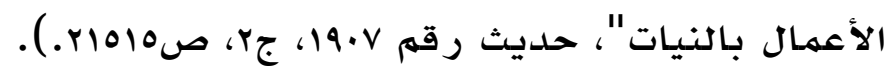


"مـن صام رمضان إيهـاناً و احتسـاباً غفر له ما تقدم مـن ذنبه " (أخرجهـ

مسلمم في صحيحه كتاب صدلاة الهسـافرين وقصر ها، هب باب التحقيـق فـي

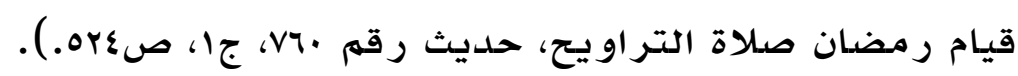

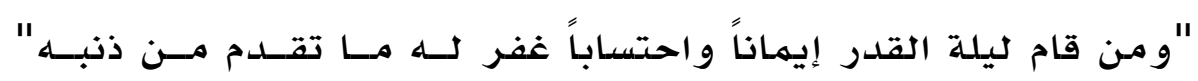
(أخر جه التر مـذي في سننه، كتاب الصدوم، بـاب مــا جــاء فـي فضـل ثـهر

$$
\text { رمضان، حديث رقه rیף، جr، صلآ. ). }
$$

r/ شـر ائط الإيمان و صفات الهسلم الحقيقي: "لا يؤمن أحدكم حتى يكون هو اه تبعـاً لهـا جئت بـه" (أخرجهـ مسلهم في صحيحهه، 17 بـاب وجـوب

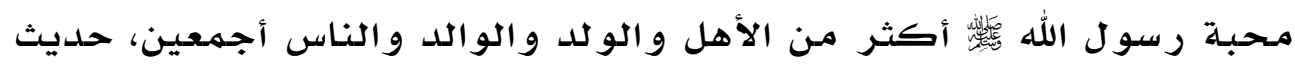

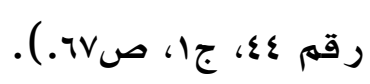

"لا يؤمسن أحلدكم حتى أكون أحب إليـه من و الـده، ووولــده و النـاس أجمعين" (أخرجهـ أحمد بن حنبـل في المسند، تحقيـق: بلدرالـدين جيشـن،

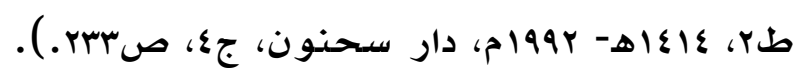
"لا يؤمن أحدكه حتى أكون أحب إليـه من نفسـه". ب/ الهـجتهـع الهسلم الذي قام على التعاليهم النبويـة: "ألا أن الهسـلهم أخو المسلهم فليس يـحل الهسلم لأخيـه ثـيء إلا مـا أحل مــن نفســه" (ســنـ أبي داود و الحسافظ، أبو داود سليهـان الأشعث، تحقيق: بدر الدين جيشن.). "ترى الهؤمنـين في تر احههم و توادهم وتعاطفهم كهثـل الجســـ إذا اشتكى منهله عضدو تداعى لله سـائر الجسلد بالحهى و السـهر "(أخر جـهـ مسـلهم، فـي كتـاب البـر و الصـلة والأدب، VI بـاب تـر احم الهـؤمنين و تعساطفهم و تعاضدهم، حديث رقم 1919 1999، ). 
ع/ مهلكات الأعمال و الأخلاق و الموانع من دخـول الجنــة: "لا يــدخل

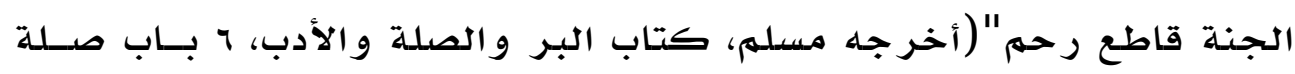

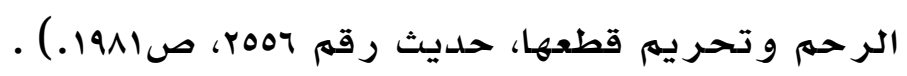

"إياكم و الحسلد فـإن الحســـ يأكـل الحسـنـات كهـا تأكسل النــار الحطب"(أخرجه أبو داود في سننه، كتاب الأدب ؟؛، باب في الحسد، حديث

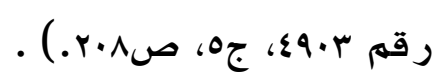

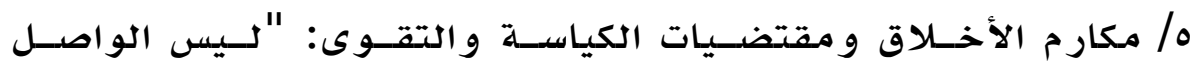

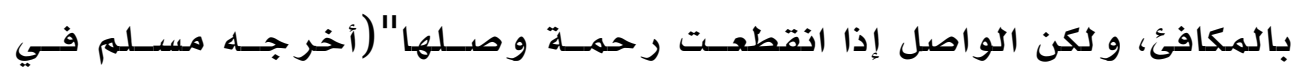
صحيحه، كتاب باب البر و الصللة، باب •1 مـا جاء في صلة الرحمن، حسديث

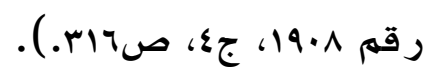

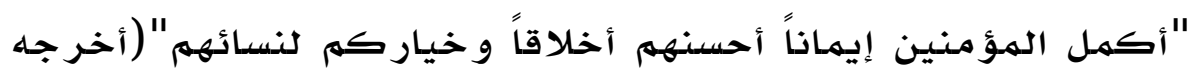

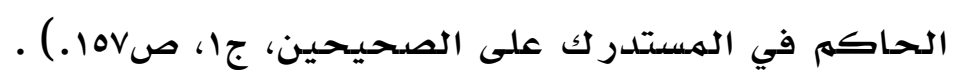

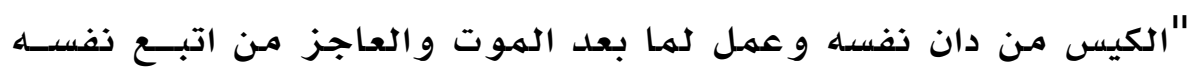

و هو اها و تمنى على الله الأماني"(أخرجه أحمد في مسنده، باب حديث شداد

$$
\text { بن أوس، حديث رقم سrاVIا، جرr، صل.0r.) . }
$$




\section{المبحث الثالث}

\section{الفوز في الدنيا والآخرة بتزكية النفس}

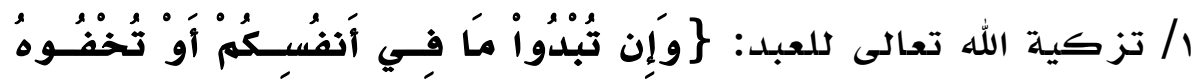

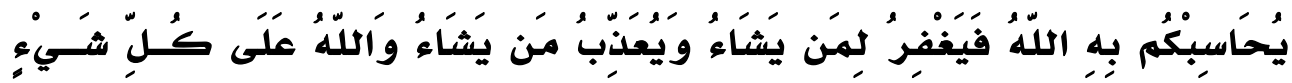

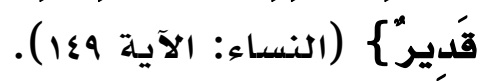

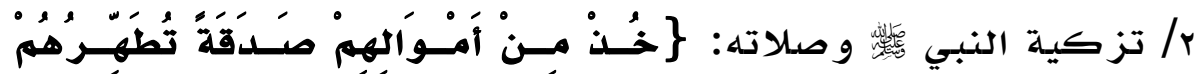

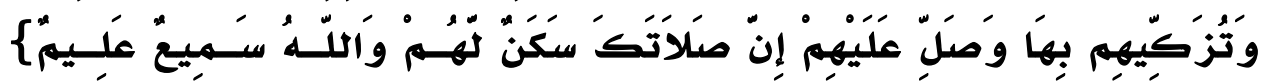
(التوبة: الآية م.1).

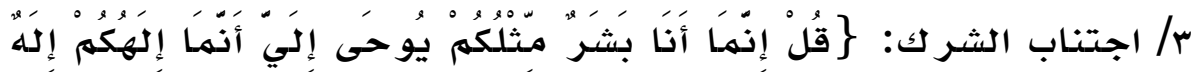

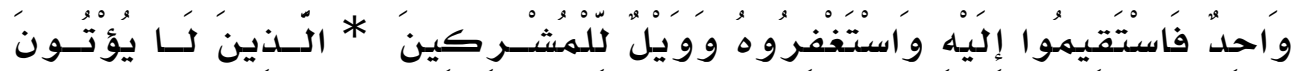

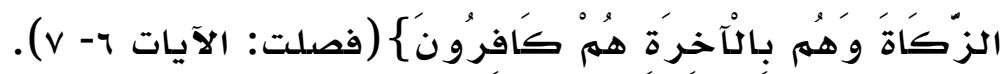

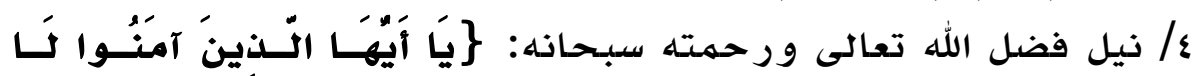

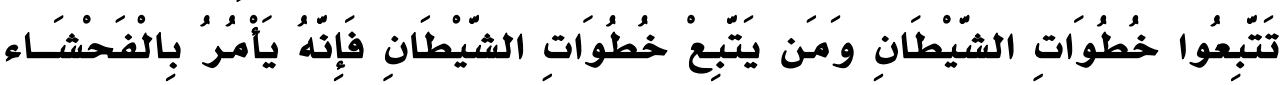

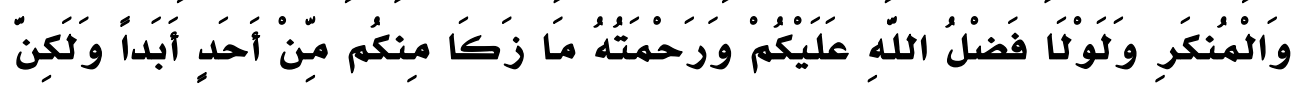

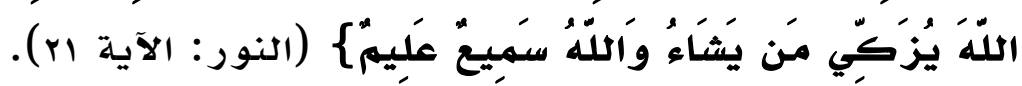

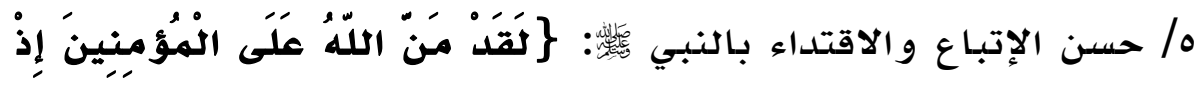

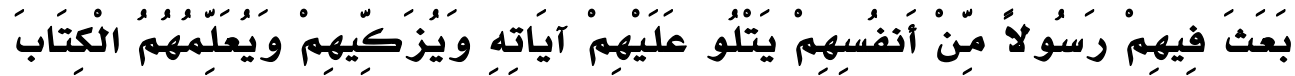

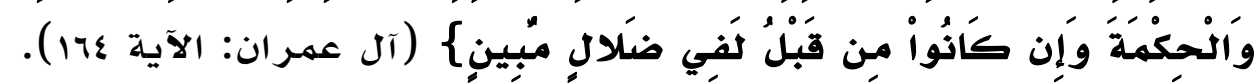

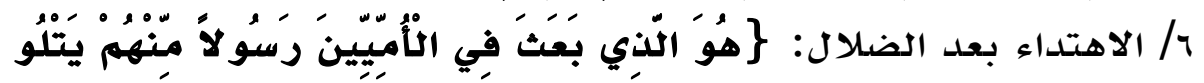

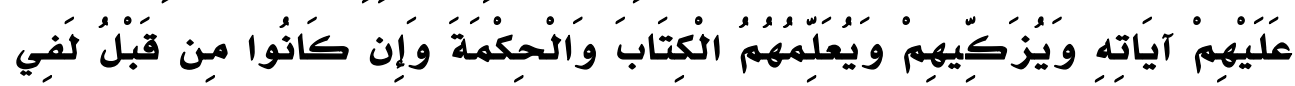

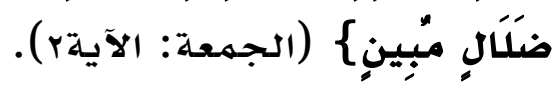

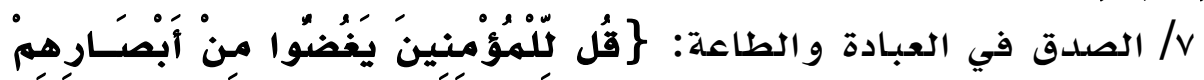

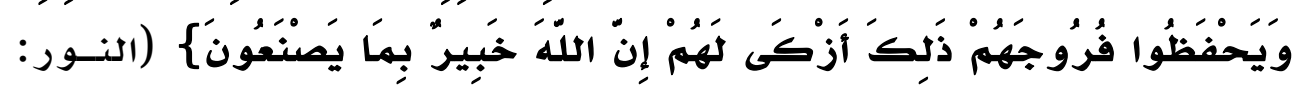
الآية .ب). 


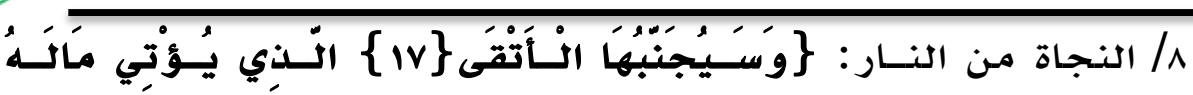
يَتَزَّكى

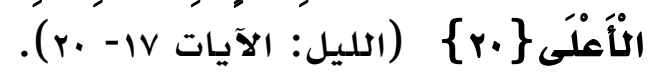

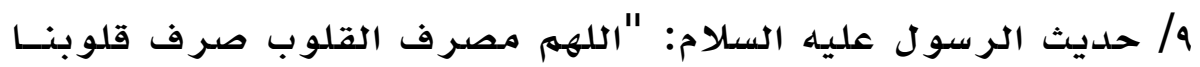

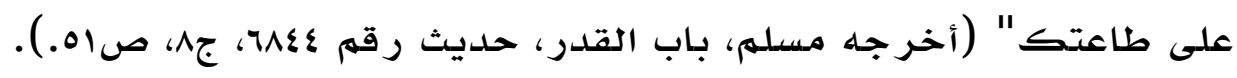

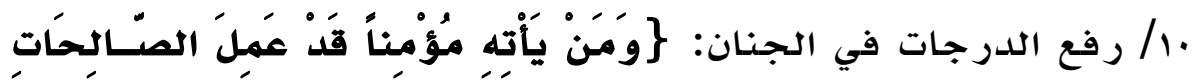

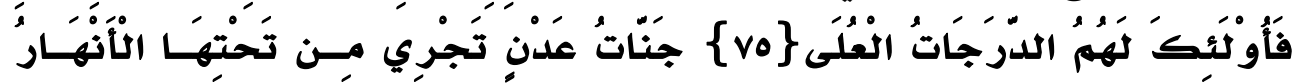

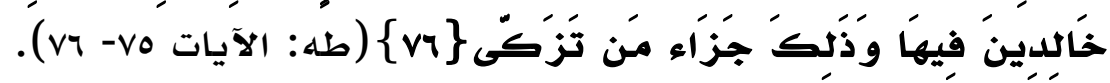

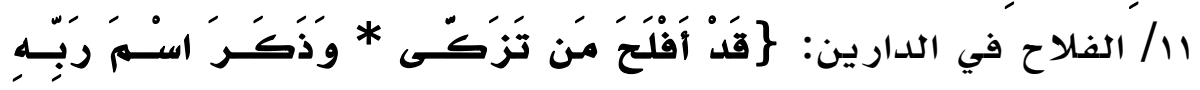

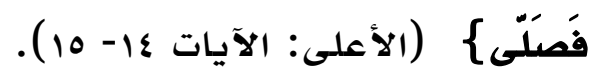

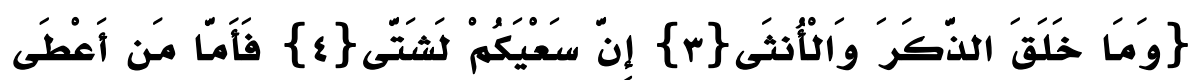

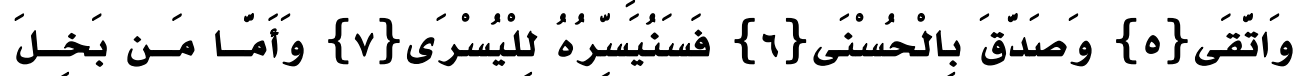

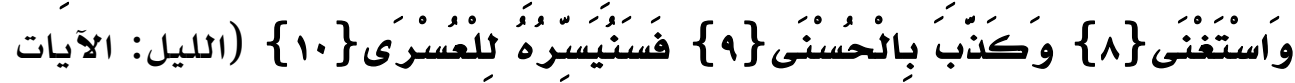
(1.) (1) (1) (1)

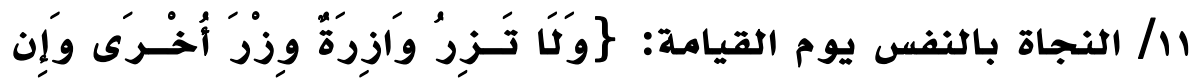

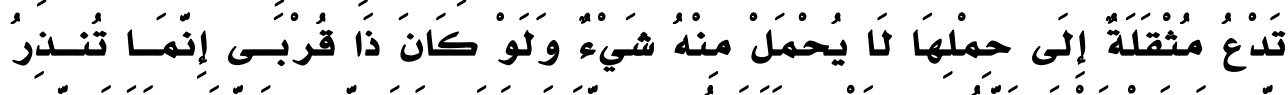

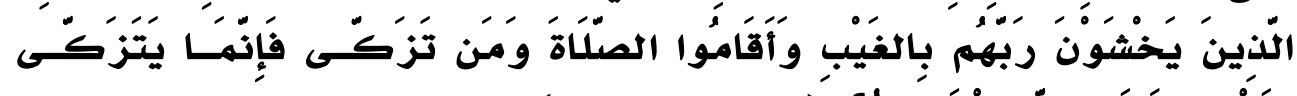

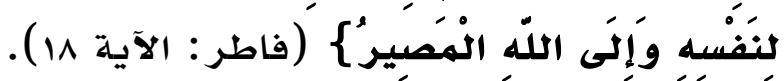

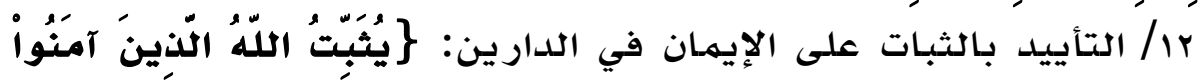

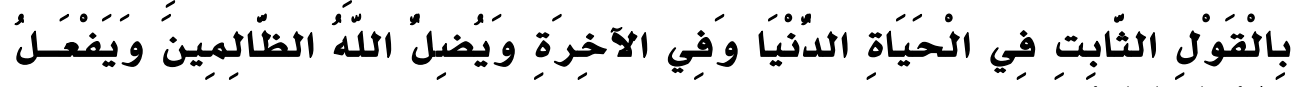

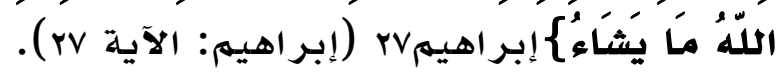

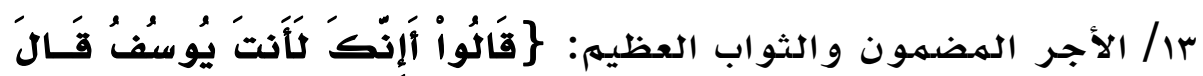

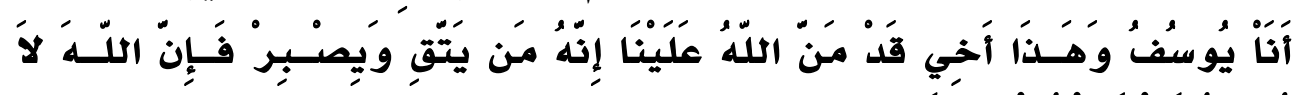

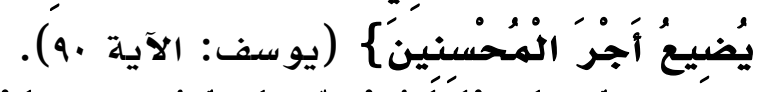

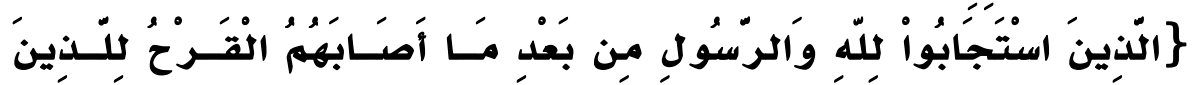

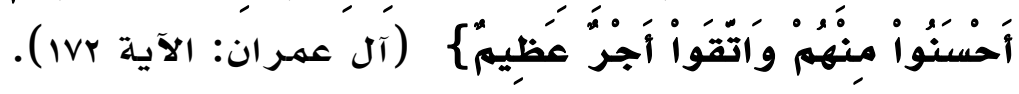




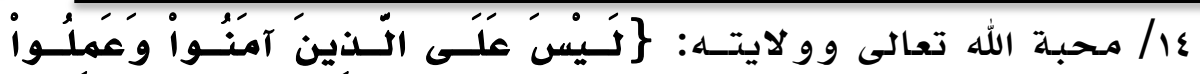

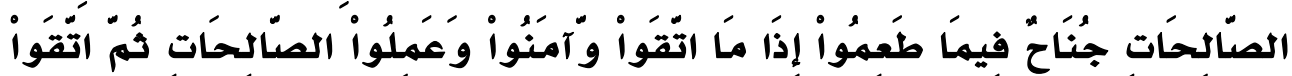

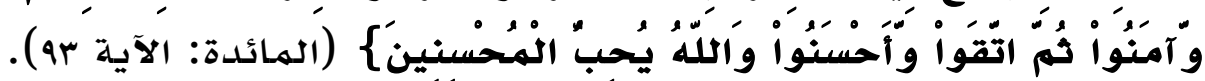

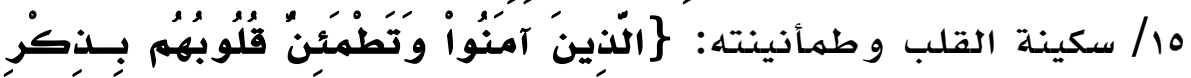

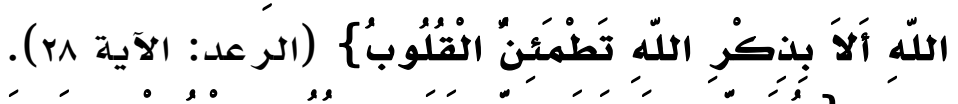

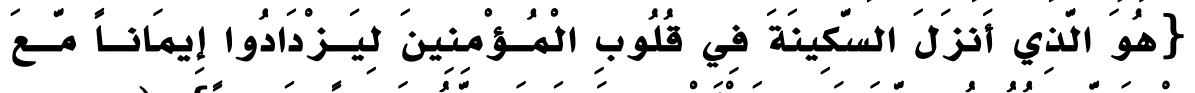

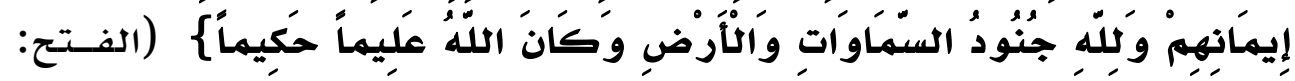

$$
\text { الآية ع ع). }
$$

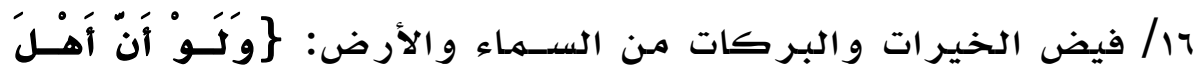

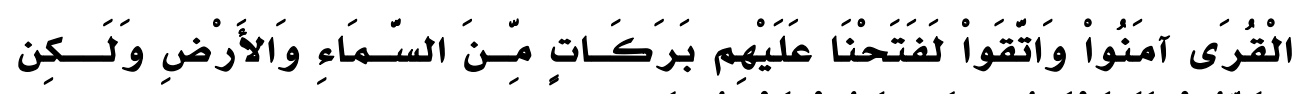

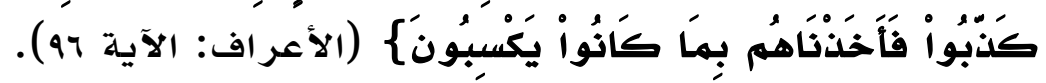

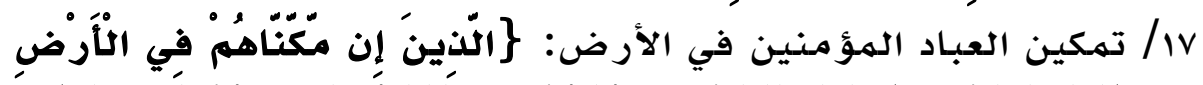

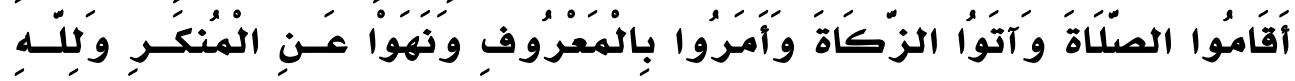

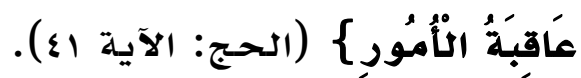

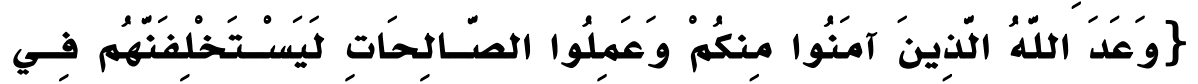

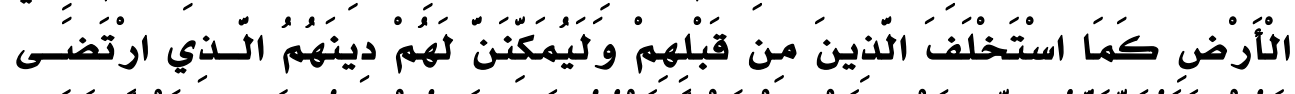

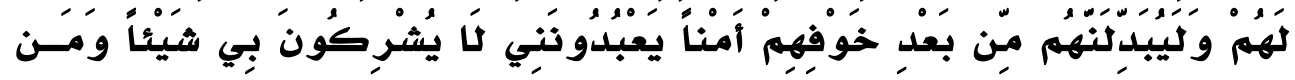

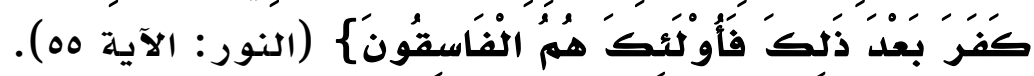




\section{الخاتمة}

الحمد الله الذي بنعمته تتم الصالحـات، لقد توصلت إلـى نهايــة هــذه

$$
\begin{aligned}
& \text { الورقة و أهم النتائج والتوصيات: } \\
& \text { أو لاً: النتائج: }
\end{aligned}
$$

ا- الاستقامـة من فو ائد تزكية النفس في الدنيا والآخرة.

r- تزكية النفس من الأدران والأوصاف الذميمة.

r- التزكية وربطها بخالقها.

ع- تزكية النفس بالقر آن الكريم و اتباع السنة.

ه- اطمئنان القلب إلى جهيل صنع الله.

ثانياً: التوصيات:

ا- العمل على تطهير النفس من أخلاقها الرذيلة كالريـاء، و العجـب،

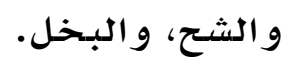

ץ- التحلي بالأخلاق الفاضلة كالإخلاص، و الإنابة، والخوف مسن الله،

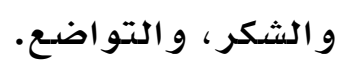

ب- تدبر القر آن فهو جلاء القلوب و إذا صفى القلب زكت النفس. ع- المحافظة على الفرائض لأنها أفضل طاعة يتقرب بها العبــد إلـى

$$
\text { ه- الإكثار من النو افل. }
$$

ج- التركيز على الدعوة الإسلامية لتزكية النفس. 


\section{المصادروالمراجع}

\section{أو لاً: القر آن الكريم. \\ ثانياً: كتب التفسير:}

ا. جامـع البيان في تأويل القر آن، الطبري، طا، ....بم، مؤسسة الرسالة. r. البيان عن تفسـير القــر آن، الثعلبـي، طا، ب...rم، دار إحيــاء التــراث

$$
\text { العر بي- بيروت. }
$$

r. الخواطر، محمد متولي الشعراوي، طا، لو991م، مطابع أخبار اليوم. ثالثاً: كتب الحديث: ع. فتح البـاري شـرح صدحيح البخــاري، لابـن حجـر العسـقلاني، دار الهعر فلة.

ه. صحيح مسله، الإمام أبو الحسن مسلهم بن الحجـاج، تحقيـق: محهـد

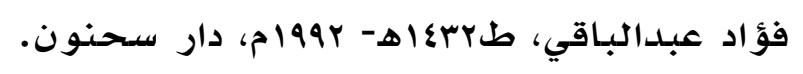

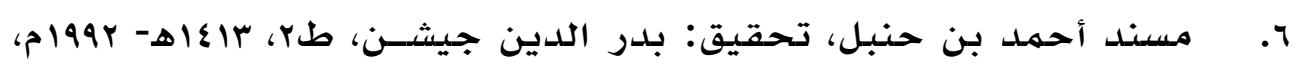

$$
\text { دار سحنون. }
$$

V. سنن أبي داود، الحافظ أبو داود سليمان الأشعث، تحقيق: بلدر الـدين

$$
\text { جيشن. }
$$

1. الهستدررك على الصحيحين.

9. الجامـع الصحيح، مسند الربيـع بـن حبيـب، إعـــاد: مسـعود عبـــالله

$$
\text { رابعاً: الكتب: الذهب، طا، ا99|م، مكتبـة مسقط- عمان. }
$$

•1. كتاب الصحاح، الجوهري، طا، 1991م، دار الكتب العلهية- بيروت.

$$
\text { 11. التعريفات، للجرجاني، طل، 1910ام، دار الكتاب العربي. }
$$


مجلة معالم الدعوة الإسلامية المحكمة- العدد (الحادي عشر)- ربيع الأول اععاهـ / نوفمبر

1 ا. لسـان العرب، ابن منظور، طا، 1999م، دار صسادر - سحنون. rا. جواهر القر آن، الغزالي، طץ، 7.عاهـ 7919ام، دار إحياء العلوم. عا. مجمهوع فتاوي أحمد ابن تيمية، م.1.

10. الوجوه والنظائر لألفـاظ كتاب الله العزيز، لابـن عبــالله الحسـين،

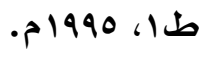

17. العقيدة والعبادة والسلولك، أبو الحسن الندوي، طب، 1999م، دار القلهمالكويت. 


\section{الهوامش}

(') الصحاح، الجوهري، جr، طا، 1991م، دار الكتب العلمية- بيروت، ص471.

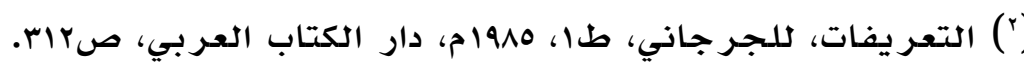

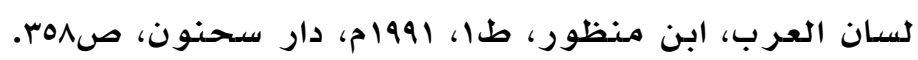

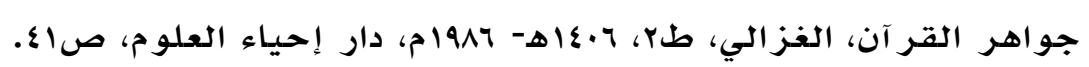

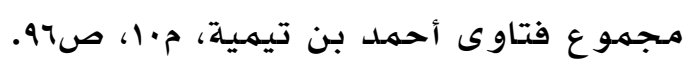

(') الوجوه و النظائر لألفاظ كتاب الله العزيز، لأبسي عبــالله الحسـين، جو، طا، (1990 1990

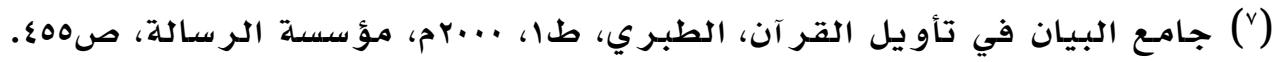

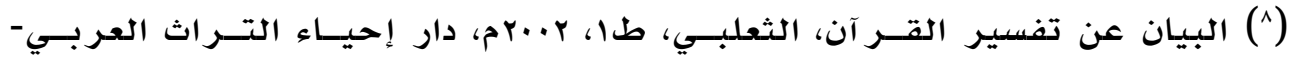

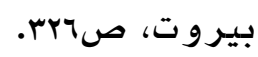

(9) الخواطر، محمد متو لي الشعر اوي، طا، 19VV، مطابع أخبار اليوم، ص1N07|.

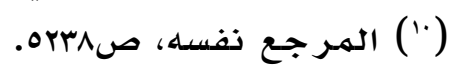

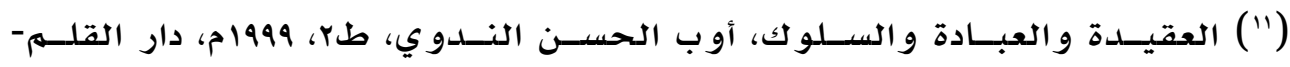

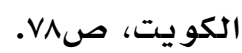

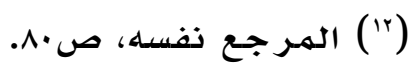

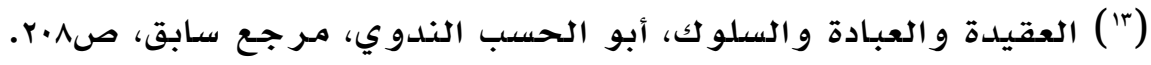

